\title{
Lifespan and mortality of old oaks - combining empirical and modelling approaches to support their management in Southern Sweden
}

\author{
Igor DROBYSHEV $^{1 *}$, Mats NIKLASSON ${ }^{1}$, Hans LINDERSON ${ }^{2}$, Kerstin SONESSON $^{3}$, Matts KARLSSON $^{1}$, \\ Sven G. NILSSON ${ }^{4}$, Jan LANNER ${ }^{5}$ \\ ${ }^{1}$ Southern Swedish Forest Research Centre, SLU, PO Box 49, SE-230 53, Alnarp, Sweden \\ ${ }^{2}$ Laboratory for Wood Anatomy and Dendrochronology, Department of Quaternary Geology, Lund University, \\ Sölvegatan 12, SE-223 62, Lund, Sweden \\ ${ }^{3}$ Malmö University, Teacher Education, SE-205 06 Malmö, Sweden \\ ${ }^{4}$ Department of Animal Ecology, Lund University, Ecology Building, SE-223 62, Lund, Sweden \\ ${ }^{5}$ Institution for Landscape Planning, SLU, PO Box XX, SE-230 53, SLU Alnarp, Sweden
}

(Received 27 August 2007; accepted 31 January 2008)

\begin{abstract}
-
- Old oaks (Quercus robur L.) play an important role in the southern Scandinavian landscape by providing habitat for a wide range of species, a large proportion of them being currently on the National Redlists.

- To provide support for the management of these trees, we review data on oak mortality and formulate a mortality-driven stochastic model analysing interactions between mortality rate, oak recruitment rate into 100-150 age class, and amount of oaks older than 200 years.

- Empirical annual mortality rates varied between 0 and $13 \%$ with average $1.68 \%$. Trees older 200 years had an average mortality rate of $1.1 \%$. Oaks in the high density forests showed higher mortality $(3.2 \%)$ as compared to the trees growing in the low density forests (1.2\%). A 400-year long modelling exercises indicated that under current mortality rates (regular mortality being centred around 1\% annually; and irregular mortality $7 \%$ with average return time of 13 years) the long-term maintenance of 20 trees older than 200 years per ha would require an input rate of 1 to 5 trees $\times$ year $^{-1} \times$ ha $^{-1}$ into the $100-150$ years old class.

- The modelling highlighted the importance of initial oak abundance affecting amount of old trees at the end of shorter (100 years) simulation period.
\end{abstract}

European hardwoods / conservation / dendrochronology / population dynamics / disturbance

Résumé - Durée de vie et mortalité des vieux chênes : une approche empirique combinée à une modélisation pour un appui à leur gestion dans le sud de la Suède.

- Les vieux chênes (Quercus robur L.) jouent un rôle important dans le paysage du sud de la Suède en procurant un habitat pour un large éventail d'espèces, une grande proportion d'entre elles étant actuellement dans les Listes rouges nationales.

- Pour appuyer la gestion de ces arbres, nous avons examiné les données relatives à la mortalité des chênes et formulons un modèle stochastique de mortalité analysant les interactions entre taux de mortalité, taux de recrutement des chênes dans les classes 100-150 ans et total des chênes plus vieux que 200 ans.

- Les taux empiriques de mortalité ont varié entre 0 et $13 \%$ avec une moyenne de 1,68\%. Les arbres de plus de 200 ans présentaient un taux de mortalité de $1,1 \%$. Dans les plus fortes densités forestières les chênes montraient une mortalité plus élevée (3,2\%) comparativement aux arbres poussant dans des forêts de densité plus faible (1,2\%). Des exercices de modélisation sur 400 ans ont indiqué qu'en dessous d'un taux courant de mortalité (mortalité courante annelle centrée autour de $1 \%$ et mortalité irrégulière de $7 \%$ avec un temps de retour de 13 ans) la maintenance à long terme de 20 vieux arbres par hectare demanderait un taux d'apport de 1 à 5 arbres par an et par hectare dans les classes d'âge de 100 à 150 ans.

- Cette modélisation met l'accent sur l'importance de l'abondance initiale des chênes qui affecte la totalité des vieux arbres à la fin d'une période courte de simulation (100 ans).

feuillus européens / conservation / dendrochronologie / dynamique de population / perturbation

\section{INTRODUCTION}

Large-diameter trees play a major role in shaping the structural and species diversity in forested ecosystems (Nilsson et al., 2002). In the southern Swedish landscape, large oaks (Quercus robur L.) provide habitat to a number of insect

* Corresponding author: Igor.Drobyshev@ess.slu.se species associated with large-diameter living, or dead trees (e.g. Ranius and Hedin, 2001). Many of these species are today red-listed (Ranius and Jansson, 2000). The dynamics of large living and dead oaks is therefore an important landscape attribute that needs a better understanding for its future effective management. However, since the year 1830, when Swedish oaks lost their protection from the king, a constant 
and rapid decline in the density of large ( $>1 \mathrm{~m}$ in diameter) oaks has been documented (Eliasson, 2004). Fire suppression introduced in Sweden over the course of 20th century is believed to cause decline in the availability of sites suitable for oak regeneration (Lindbladh et al., 2003; Löf, 2001; Niklasson et al., 2002). Existing oak-dominated woodlands have been experiencing extensive logging and conversion into predominately spruce monocultures (Eliasson, 2002). Recent studies have shown that regional decrease in the oak abundance puts at risk the survival of species associated with large oaks and have called for the development of appropriate management strategies aimed at the preservation of oak and, in particular, the provision of large-diameter and hollow trees (Hedin, 2003).

Causes of oak tree mortality are complex and likely involve direct and indirect agents (Osipov, 1989; Thomas et al., 2002). For practical purposes, total mortality has been viewed as the sum of regular internal mortality due to competition and senescence (Franklin et al., 1987; Shugart, 1987) and irregular external mortality due to exogenous disturbance agents like wind, drought, insect outbreaks, and fires (Demchik and Sharpe, 2000; Naumenko, 1949; Pedersen, 1999; Shugart, 1987). Under natural conditions, the probability of a regular mortality varies over tree's lifespan with higher mortality in early years, relatively "safe" mid-ages, and somewhat higher probability of death at the end of its lifespan (Monserud and Sterba, 1999). A decrease in tree density over a stand's "lifespan" lowers the importance of competition-related regular mortality (Silvertown and Charlesworth, 2001). Instead, the importance of irregular mortality generally increases as trees or stands become older. Irregular mortality should thus dominate among large stand-alone trees. In this case, the timing of death events should be less stand-specific and should respond more to regional variation in environmental conditions or climatically-driven single events known to cause tree death (e.g. windstorms, frost events, or droughts).

Under more controlled conditions, as is the case in most managed forests, the competitive interactions among trees for water, nutrients and light are partly taken out of action by thinning. Mortality functions used to predict losses of timber consider mortality as a chance event, its probability being a function of the tree's expected longevity (Shugart, 1987). In computational terms, mortality is typically considered a dependent variable in logistic regression where independent factors typically include diameter, diameter increment, basal area and derivatives of these variables (Monserud and Sterba, 1999; Zhao et al., 2004). The commercially-meaningful mortality in managed stands is therefore frequently modelled as regular that results in overall mortality estimates being relatively low. For example, single disturbance events (e.g. climaticallyinduced droughts or windstorms), potentially providing an order of magnitude larger impact on mortality rates (compared to senescence mortality, for example) are often not actually considered. This naturally limits application of such models for the study of stand-along trees in semi-natural environments.

In this paper we review existing information on oak mortality rates and use this knowledge in a modelling exercise aimed at providing support for the management of old ( $>200$ years) oaks in southern Swedish biogeographical context. The focus of this study is on the amount, expressed as trees per ha, of old oaks trees subject to different types of mortality events. We consider oak mortality as a sum of regular (due to competitive interactions and senescence) and irregular (or event) mortality, resulting from single large mortality events. By doing so, we aim at providing a quantitative assessment of the amount of old oaks to be preserved under conservation strategies which aim at different "equilibrium" densities of oak trees in a landscape. We review both regular and irregular mortality rates observed in studies on permanent plots or through re-inventories of single trees over different time periods. We then take advantage of this information to formulate a simple mortality-driven statistical model, which is later applied to quantify interplay between oak recruitment into 100-150 year cohort within a landscape/stand, mortality rate, and amount of oaks older than 200 years, present in such a landscape or stand. Due to the limited amount of empirical data on age, growth, and mortality of large oaks, the estimates of mean rate and its variation contain a considerable amount of uncertainty. To handle this uncertainty mortality estimates were defined as statistical distributions with certain mean tendency and its variation. By allowing the mean and its variation to change among different model runs we assess the sensitivity of the model outcome to the initial input parameters and different rates of assumed mortality. Finally, we discuss management implications of model results and limitations of the study.

\section{STUDY AREA}

The Swedish component of the data analyzed in the paper originated in the counties of Scania, Blekinge, Halland, Kronoberg, and Västra Götaland. The mean annual temperature in this part of southern Sweden is between $5{ }^{\circ} \mathrm{C}$ and $8{ }^{\circ} \mathrm{C}$. The mean temperature in January varies between $-4{ }^{\circ} \mathrm{C}$ and $0{ }^{\circ} \mathrm{C}$, in July between $15^{\circ} \mathrm{C}$ and $16^{\circ} \mathrm{C}$. There is a large variation in precipitation between the western (up to $1200 \mathrm{~mm} / \mathrm{y}$ ) and the eastern $(500 \mathrm{~mm} / \mathrm{y})$ part of the region. The typical range is within $600-1000 \mathrm{~mm} / \mathrm{y}$. West or south-west winds prevail. Growing period with mean daily temperature above $5{ }^{\circ} \mathrm{C}$ lasts for 180-240 days (Nilsson, 1996). The soils of the studied sites bear a history of glacial dynamics and were formed on sandy and stony moraines (Fredén, 2002). The region lays in the nemoral and boreo-nemoral zones (Ahti et al., 1968), where the boreal and temperate biomes prevail. Norway spruce (Picea abies (L.) Karst.) and Scots pine (Pinus sylvestris L.) are the main coniferous species. Oaks (Quercus robur L. and $Q$. petraea (Matt.) Liebl.), European beach ( $\mathrm{Fa}$ gus sylvatica L.), and small-leaved species (downy birch, Betula pubescens Ehrh. and quaking aspen, Populus tremula L.) represent deciduous component in the forest cover.

\section{MATERIALS AND METHODS}

\subsection{Review of the literature data}

To assess the empirically observed range of oak mortality rates we reviewed published studies from where annual oak (mostly Quercus 


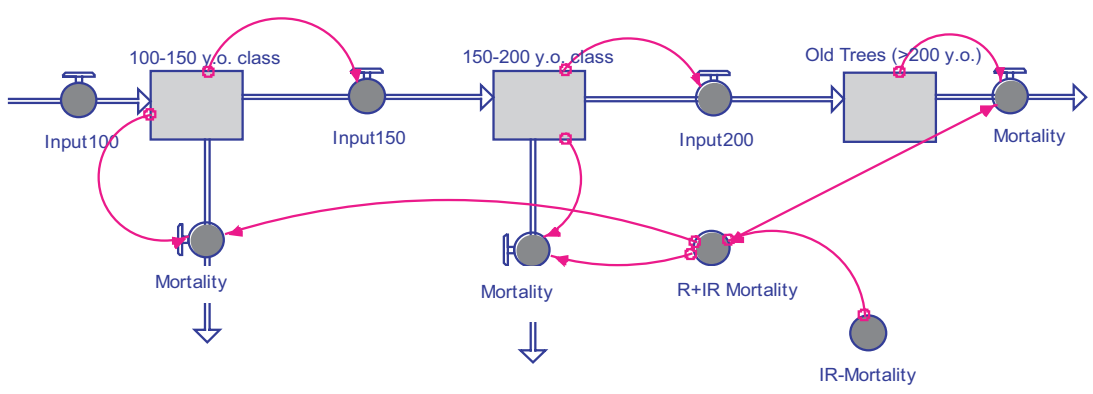

Figure 1. Graphical description of mortality-driven model of oak density. Trees "enter" the model as flow into 100-150 year old class and then proceed to the 150-200 years old class and finally - to the "old trees" class (trees $>200$ years old). Mortality represented as a sum of regular (R) and irregular mortality (IR) acts to decrease the number of trees in each of the classes. Initial input rate into the 100-150 year old class and irregular mortality rates are defined as distribution functions. Input into two older classes is a function of the amount of trees in the previous class.

robur and occasionally $Q$. petraea) mortality rates could be extracted. In selecting this data, we did not consider studies where no age and stand density data were presented or were possible to obtain from other literature sources. Since exact density data were not always available, we grouped all studies into three groups: studies where overstory density was (1) above 100 tree/ha, (2) below 100 trees/ha, and (3) unknown or varying.

Mortality rates were calculated as annual mortality rate $=$

$$
1-\left(C / N_{0}\right)^{1 / y}
$$

where $C$ is the number of currently recorded living trees, $N_{0}$ original number of living trees, $y$ - number of years between resamples. Some of the reviewed mortality rates were originally calculated as the ratio dead/initial number of trees and no additional data were available to recalculate the mortality in its exponential form. The data have been collected during re-inventories of the permanent study areas or plots (Tab. I). Most of the mortality rates reviewed were based on the number of trees and three estimates were volume-based assessments.

Since in most of the studies reviewed it was possible to extract amount of dead trees and total amount of trees sampled, we calculated average annual mortality as weighted mean of all mortality estimates, where weights were the proportion of trees sampled in a study to the total numbers of trees sampled. We then bootstrapped original dataset 1000 times to provide estimates of the variability in the mortality rates (Efron and Tibshirani, 1994).

To evaluate the role of stand age and stand density in affecting oak mortality rates we run Yates corrected Chi-square tests (Sokal and Rolf, 1995) between age and habitat type contrasts.

\subsection{Mortality rates from coupled stand-level and regional assessments}

To account for variation in oak mortality likely arising from differences in site conditions within the same region we also searched for coupled site- and region-level inventories of oak mortality. For this purpose, we obtained coupled assessments of (a) the total area of a landscape suffering episodes of high oak mortality and (b) the mortality rates within and outside affected landscape patches from the dataset on a wave of oak dieback that occurred in the Voronezh region, south-west Russia, during 1943-1944 (Naumenko, 1949). For this study, probability of dying for a tree in the whole area $\left(M_{\text {total }}\right)$ was calculated as

$$
M_{\text {total }}=M_{\text {patch }} A_{\text {patch }}+M_{\text {outside }} A_{\text {outside }}
$$

where $M_{\text {patch }}$ is the probability of dying within affected patch occupying $A_{\text {patch }}$ proportion of the area, and $M_{\text {outside }}$ is the probability of dying in matrix occupying $A_{\text {outside }}$ proportion of the area, with $A_{\text {patch }}+A_{\text {outside }}=1$.

\subsection{Description of the model}

The modelling exercise was designed to assess the relationships between an initial amount of oak trees in 100-150 year age class (i.e. the initial value at the start of the run), mortality rates, and the resulting abundance of oak trees older 200 years over 100 and 400 year time perspectives (Fig. 1). In the model, oak population was represented by three age cohorts: trees between 100 and 150 years old, 150-200 years old, and older 200 years old. In the model, we did not consider dynamics of trees younger than 100 years old. This cohort was present in the model only as a supplier of the trees to the 100150 years cohort. The rate of tree input into $100-150$ year cohort varied between 0 and 5 trees annually depending on the type of the model run (see below). Dynamics of trees within a cohort was regulated by (1) input rate from the previous cohort, (2) transition of the trees into older cohort (for 100-150 and 150-200 year cohorts), and (3) mortality rate within a cohort. Transition of the trees to an older cohort was modelled by moving 0.02 (1/50th) part of the content in the younger age class to the older class every year. This assumed that tree ages were evenly distributed within each age class.

The main variable of interest in the modelling exercise was the amount of oaks per ha, which were older than 200 years. There is little empirical knowledge on the oak age distribution in natural and seminatural forests, especially concerning the very old trees ( $>200$ years old). In the model we considered the amount of such old trees as a function of the amount of trees in the 150-200 year old group, which, in turn, was a function of the amount of trees within 100-150 year old group. The purpose of such two-step design was to relate dynamics of old oaks our model to younger cohorts. In Southern Sweden the rotation time for commercial oak stands is around 120 years (Löf, 2001) and data on their densities is commonly available.

We assumed that modelled oaks exist in a woodland-type environment with low (around and below 100 trees/ha) overstory tree density where density- dependent mortality is minimal, as compared to age-related mortality and mortality during single disturbance events (Pontailler et al., 1997; Wolf et al., 2004). Mortality in the model was decomposed into the sum of regular mortality (RM) and irregular or 


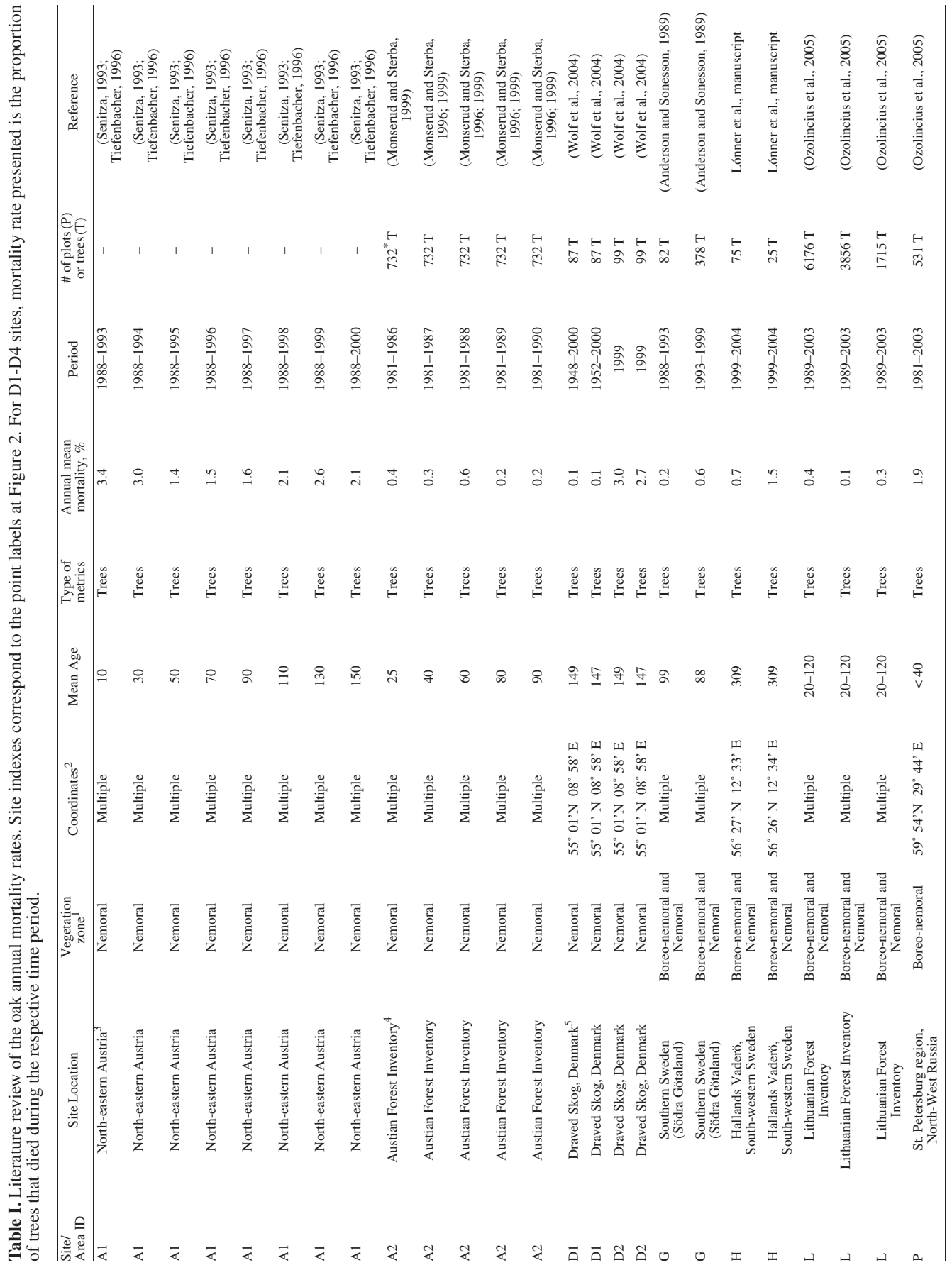




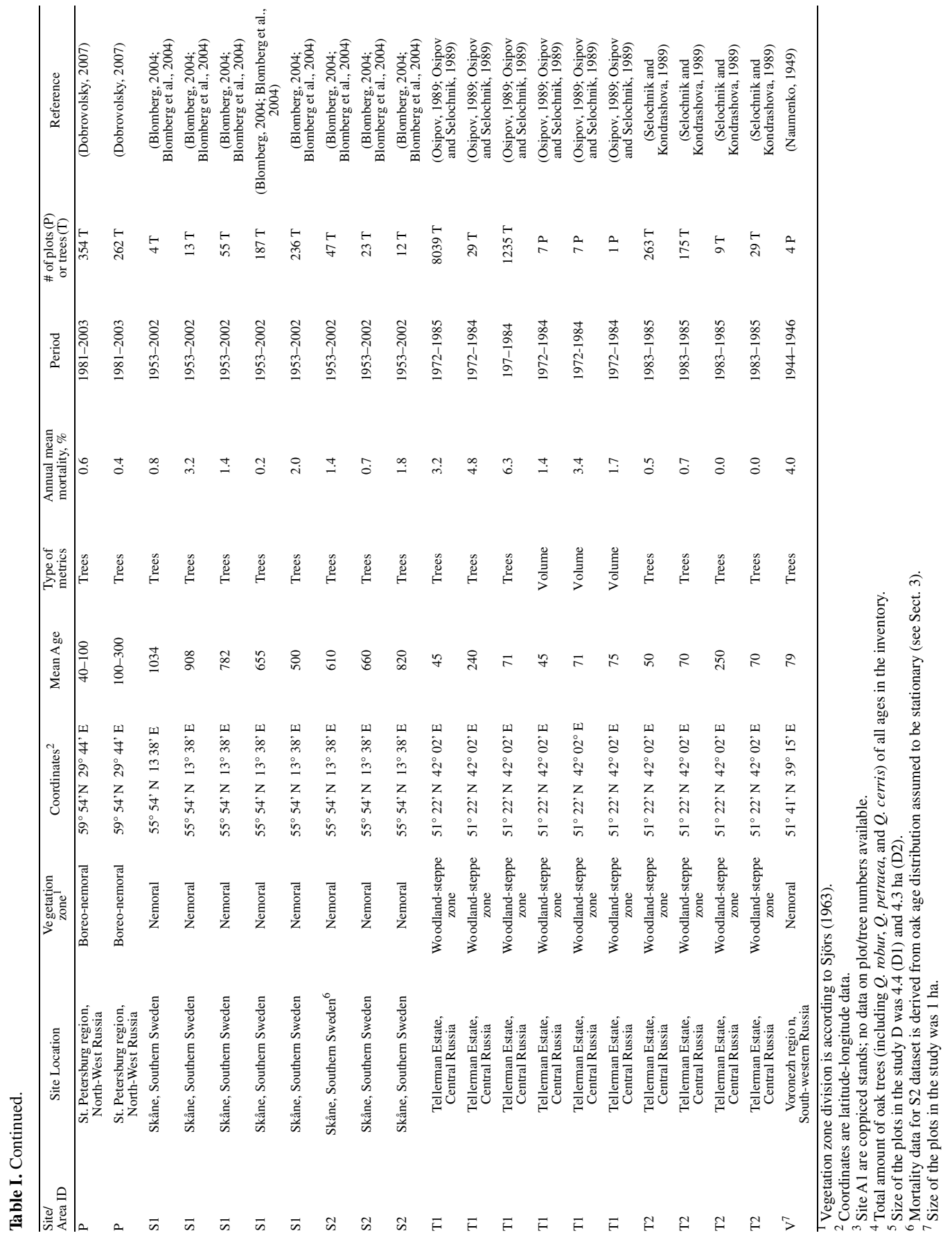


event mortality (IM). In both cases mortality acted at the annual scale. Regular mortality varied according to the Poisson distribution, with the parameter $\lambda$ estimated from published rates (Tab. I, see Sect. 4). Irregular mortality was modelled as a pulse in the proportion of the dying trees with a certain amplitude and frequency. Frequency of mortality episodes was represented by Poisson distribution with predefined $\lambda$ parameter $(20,13,15$, or 20 years $)$. Amplitude of mortality episodes was represented as distribution obtained by (1) generating a Poisson distribution with $\lambda$ parameter centred at predefined value (e.g. 10 for representing annual mortality level of $1 \%$ ), and (b) reducing each value in the distribution by a factor (following the previous example, by 1000). Such two-step procedure would allow us to use the Poisson distribution while working with annual mortality rates represented as percentage of trees died. The same procedure was also applied for generating regular mortality in the model.

We assumed that IM is a multiplication of two probabilities: the probability of a large mortality event $(F i)$ taking place at a certain time interval $\left(P_{F i}\right)$ and the probability of dying during this event $\left(P_{M / F i}\right)$ :

$$
\mathrm{IM}=\left(P_{F i}\right) \times\left(P_{M / F i}\right) .
$$

In the model we defined 16 levels of disturbance intensity to cover variation in the natural mortality rates in oaks older 100 years (see following sub-section). Each level of disturbance intensity was a combination of disturbance frequency and intensity. Mortality was applied to all age cohorts and we assumed no additional oak mortality due to timber harvesting. By allowing variation in irregular mortality and keeping regular mortality rate constant and low, we assumed that irregular mortality dominated over regular (age-related) mortality. We based this assumption on studies suggesting that (1) low "background" mortality (regular mortality in our study) is accompanied by episodes of high mortality (irregular mortality), and that (2) impact of irregular mortality tend to be larger than the impact of the regular mortality (Auclair et al., 1996; Osipov and Selochnik, 1989; Wolf et al., 2004).

Each of the 16 combinations of input and mortality rates (four levels of input rates times four levels of mortality rates) was run 100 times to produce a distribution of oak input values and corresponding values for the amount of old trees at the 100 and 400 years since the start of simulation. Selection of the "stop" times (termination years for model runs, 100 and 400 years) was aimed at depicting (a) a state of the modelled system which was still influenced by the initial parameters (values assigned to variables at the beginning of the simulation) and (b) a state depending almost exclusively on the defined input rate of oaks. Finally, we analysed distribution of the oak densities in the $>200$ year class to assess the probability of maintaining three subjectively defined threshold levels. These levels were 2, 5 and 20 trees/ha were both expert and reconstruction-based estimates of historical oak densities in Southern Sweden (see following subsection). We computed the average density and the lower 5\% distribution limit of density for each combination of input and mortality rates. It was assumed that a scenario meets a particular threshold $(2,5$, or 20 trees/ha) if the lower 5\% distribution limit for the oak density was equal or larger than that threshold.

\subsection{Calibration of the model}

We calibrated (a) input rates of oak into the 100-150 year cohort, (b) initial oak cohort densities, (c) one level of regular mortality, and (d) four levels of oak irregular (event) mortality.
The input rate of oaks into the 100-150 year class was allowed to acquire random values within four selected ranges: $0-0.01 ; 0.01-$ $0.05 ; 0.05-1$; and $1-5$ trees/(ha $\times$ year). The selected ranges were expert estimates based on our knowledge of southern Swedish oakdominated forests and woodlands and a reference dataset from a $52 \mathrm{~km}^{2}$ ha Stenbrohult landscape in the province of Kronoberg in Southern Sweden (Ask and Nilsson, 2005; Lindbladh and Nilsson, 1999). The lowest input rate represented situation, rather common in Southern Swedish context, where stands with old oak cohorts had almost no oak regeneration. In turn, the highest input rate group was characteristic of the stands with continuous oak regeneration. For example, an input rate value of 5 corresponded to a landscape were average annual contribution of the $0-100$ year cohort to the 100-150 class would be five trees, translating into the input of 500 trees over the course of a century. This estimate roughly corresponded to the Stenbrohult landscape, where the total mean density of oak (both in the lower and upper canopy) was about 400 trees/ha (Ask and Nilsson, 2005; Lindbladh and Nilsson, 1999).

Initial values for the age classes were set as following: 100150 year class - 70 trees/ha; 150-200 year class - 4 trees/ha; $>200$ year class -4 trees/ha. The values were based on a reference dataset from Stenbrohult landscape (Fig. 1) (Ask and Nilsson, 2005; Lindbladh and Nilsson, 1999) and results from the ongoing study of the oak population at Hallands Väderö, an island at the south-west Swedish coast.

Regular mortality was centered around 0.01 , a value which was based on empirical estimates from regional inventories where no episodes of event mortality were reported (Tab. I, see also Sect. 4).

The levels of irregular mortality were based on compilation of published mortality rates (see Sect. 4 and Tab. I) and two reference landscapes. Among the published rates we selected those obtained during the periods of known oak declines (Naumenko, 1949; Osipov, 1989; Osipov and Selochnik, 1989), assuming that the reported mortality rates represent oak mortality during environmentally stressful years and can, therefore, be viewed as irregular mortality. The rates in each of these studies varied between 6 and $13 \%$ (Voronezh region, (Naumenko, 1949)) and between 1.8 and 6.3\% (Russian foreststeppe zone, (Osipov, 1989; Osipov and Selochnik, 1989). These data, however, was obtained on younger trees than those analysed in the model (Tab. I). The only long-term mortality estimates for old trees (> 200 years old) were available from two Swedish landscapes: Hallands Väderö and Stenbrohult (Fig. 1). Although these rates were not related to a single disturbance event and were not, therefore, true estimates of irregular mortality, they represented cumulative outcome of different types of mortality events and could thus be used to assess the soundness of selected mortality levels. At Hallands Väderö oak population consists of approximately 400 trees about 350 years old. Within these landscapes tree-ring-based methods and analysis of historical documents were used to reconstruct age structure and density dynamics of oak population over the last two to three hundred years. Reconstruction suggested that over the last hundred years the density of oaks dropped from about 10-30 trees per ha down to approximately 4-5 trees per ha. No recruitment into the higher canopy took place in this forest over the last century. At Stenbrohult, over the last 125 years the oak density dropped from about 15 trees per ha to less than one tree per hectare. Four levels of irregular mortality were partitioned as following: mean amplitude 0.03 (death of $3 \%$ of all trees within a stand) at a mean return interval of 20 years; 0.05 at a 15 year interval; 0.07 at 13 year interval; and 0.1 at a 10 year interval. Thus, rate of change in oak abundance at Hallands Väderö corresponded to 


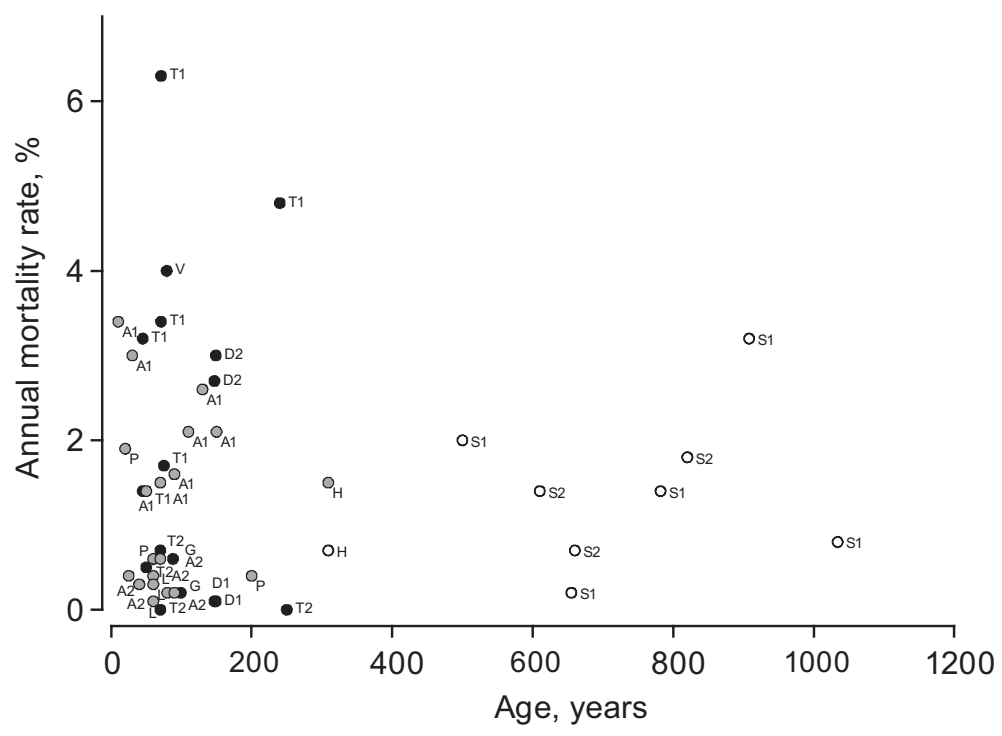

Figure 2. Relationship between age and mortality rates for re-inventoried sites/areas in Europe. Point labels refer to the study codes listed in Table I. Colour of the symbols indicates overstory density in respective studies: above 100 trees/ha (black circles), below 100 trees/ha (white), and unknown or varying (grey).

a low mortality level (M1), whereas density dynamics in the Stenbrohult landscape corresponded to average (M3) or high (M4) mortality levels. These two areas have not been subject to traditional management and were, therefore, more similar to a semi-natural area rather than to a typical production-oriented area.

Generally, the lowest disturbance intensity (3\% in irregular mortality occurring with the frequency of 20 years) represented habitats with low level of exogenous disturbance, generally corresponding to the disturbance levels in other temperate forests (Franklin et al., 1987; Pedersen and McCune, 2002). The highest level of disturbance intensity represented conditions of repeated episodes of high oak mortality similar to those reported earlier for the European part of Russia (Osipov, 1989; Selochnik, 1989). In our set of four mortality levels, frequency and amplitude of mortality events were positively correlated. Although general considerations may rather suggest a negative correlation between disturbance frequency and amplitude, we adopted this approach since we wanted to analyze the dynamics of oak along a gradient of disturbance intensity (frequency $\times$ amplitude). Resulting set of mortality levels help therefore represent variability partly represented in our reference landscapes (Halland Vaderö and Stenbrohult).

\section{RESULTS}

\subsection{Mortality rates}

Annual mortality rates in oak stands varied between 0 and $6.3 \%$ with the mean $1.68 \%$ (2.5 and $97.5 \%$ confidence limits, CL being 0.21 and $3.89 \%$ ) (Tab. I and Fig. 2). Most of this variation was observed in the studies where average age of oak did not exceed 150 years. For the studies with the oak average age being within 0-100 years, mean mortality was $1.60 \%$, $n=23563$, CLs being 0.16 and $3.91 \%$; and for 100-150 years interval $-1.07 \%, n=634$, CLs being 0.21 and $1.92 \%$. No studies concerning oak with average age within 150-200 years old were available. In four studies/datasets average age was above 200 years, and for this group the mean annual mortality rate was $1.01 \%, n=977$, CLs being 0.47 and $2.02 \%$. None of differences in mortality rates between age groups were significant ( $p \geq 0.17$, Chi-square value $\leq 1.86$ ). The estimates for the oldest trees in this review ( $>400$ years old) originated in the Swedish province of Scania and thus might represent only southern Swedish situation.

Oaks in the stand with density above 100 trees/ha highdensity forests showed higher mortality $(3.21 \%, n=10611$, CLs 0.11 and 8.42) as compared to the trees growing in the stands with density below 100 trees/ha $(1.24 \%, n=652$, CLs 0.38 and $2.56 \%$ ). Mean mortality was the lowest for the sites with various or undetermined density $(0.35 \%, n=13834$, CLs 0.10 and $0.72 \%$ ). All differences in mean mortality rate among stands density contrasts were significant at least at $p \leq 0.006$ (Yates corrected Chi-square $\geq 7.69$ ).

Mortality levels of one order of magnitude higher were recorded in the south-west Russia during 1943-44 (Tab. II). The overall probability of mortality was estimated to vary between 6 and $13 \%$ annually, given the consideration of mortality rates both in the heavily affected areas and in the lessaffected matrix.

\subsection{Modelling of long-term management scenarios}

To reach an average of 2 living oaks per ha within 100 years since the start of the simulation required virtually no input of oak into 100-150 year old class, irrespectively of the mortality rates defined (Tab. III). Except a contrast with the highest mortality level, meeting the threshold of 5 trees $\times \mathrm{ha}^{-1}$ would occur at all combinations of input and mortality rates. Meeting the 20 trees/ha threshold would require the input rate reaching 
Table II. Oak mortality recorded in the Voronezh region, south-west Russia, during 1943-44. Mortality pattern within four forest estates is a product of (a) the proportion of the area under heavily affected patches (column 2), and (b) the mortality rates within (column 3) and outside heavily affected patches (4\%), (Naumenko, 1949). See Methods section for details of calculations. Data is from Naumenko (Naumenko, 1949).

\begin{tabular}{llll}
\hline Location & $\begin{array}{l}\text { Area affected } \\
\text { ha (\% of total area) }\end{array}$ & $\begin{array}{l}\text { Proportion of trees } \\
\text { died, } \%\end{array}$ & $\begin{array}{l}\text { Probability of dying } \\
\text { in the whole area, } \\
\text { for a tree in \% }\end{array}$ \\
\hline Voronezh nature reserve & $1500(16)$ & 52 & 12 \\
Forest estate of Voronezh silvicultural institute & $400(6)$ & $50-70$ & $7-8$ \\
Annensky forest estate & $160(3)$ & $60-90$ & $6-7$ \\
Kalachaevski forest estate & $4306(29)$ & $12-36$ & $6-13$ \\
\hline
\end{tabular}

Table III. Result of model runs for the $4 \times 4$ combinations of input rates ( $I 1$ through $I 4)$ into $100-150$ year old age class and levels of irregular mortality ( $M 1$ through $M 4$ ). Data - mean and the lower 5\% distribution limit (in italics) for the number of trees older 200 years per ha 100 years (above line) and 400 years (below line) after the start of simulation. $a$ refers to the amplitude and $f$ - to the frequency of the irregular mortality, which define one of the four levels of mortality levels (M1 through $M 4)$. Each pair of mean and 5\% threshold values is based on the distribution of tree densities from 100 model runs.

\begin{tabular}{|c|c|c|c|c|}
\hline \multirow{2}{*}{$\begin{array}{l}\text { Input, } \\
\text { tree/(ha } \times \text { year) }\end{array}$} & \multicolumn{4}{|c|}{ Mortality levels } \\
\hline & $\begin{array}{l}M 1 \\
a-0.03 \\
f-20\end{array}$ & $\begin{array}{l}M 2 \\
a-0.05 \\
f-15 \\
\end{array}$ & $\begin{array}{l}33 \\
a-0.07 \\
f-13 \\
\end{array}$ & $\begin{array}{l}M 4 \\
a-0.10 \\
f-10\end{array}$ \\
\hline $\begin{array}{l}I 1 \\
0-0.01\end{array}$ & $\frac{13.7,11.9}{0.9,0.6}$ & $\frac{11.1,7.7}{0.5,0.3}$ & $\frac{9.0,5.8}{0.2,0.1}$ & $\frac{5.1,2.5}{0.1,0.0}$ \\
\hline $\begin{array}{l}I 2 \\
0.01-0.05\end{array}$ & $\frac{14.0,9.9}{1.8,1.1}$ & $\frac{11.1,8.4}{1.1,0.6}$ & $\frac{9.1,6.3}{0.7,0.3}$ & $\frac{5.2,2.8}{0.4,0.1}$ \\
\hline $\begin{array}{l}I 3 \\
0.05-1.00\end{array}$ & $\frac{20.0,15.0}{19.7,3.7}$ & $\frac{17.0,11.8}{19.6,3.9}$ & $\frac{14.0,7.6}{14.4,3.1}$ & $\frac{8.2,4.9}{10.9,2.1}$ \\
\hline $\begin{array}{l}I 4 \\
1.00-5.00\end{array}$ & $\frac{51.4,28.2}{105.8,40.3}$ & $\frac{44.8,24.9}{78.6,32.0}$ & $\frac{38.0,20.0}{60.4,24.3}$ & $\frac{25.8,11.3}{33.8,12.4}$ \\
\hline
\end{tabular}

0.05-1 trees $\times$ year $^{-1} \times$ ha $^{-1}$ under the lowest mortality rate and $1-5$ trees $\times$ year $^{-1} \times$ ha $^{-1}$ under all four mortality rates.

The results were quite different if simulation runs were extended to 400 years. Threshold of 2 trees $\times$ ha $^{-1}$ would be possible to meet only at the input rates above 0.05 1 trees $\times$ year $^{-1} \times \mathrm{ha}^{-1}$. In turn, meeting threshold of 5 trees $\times$ ha $^{-1}$ would require the highest input rate (15 trees $\times$ year $^{-1} \times$ ha $^{-1}$ ) under any of the mortality rates. Input of $1-5$ trees $\times$ year $^{-1} \times$ ha $^{-1}$ also ensured meeting 20 trees $\times$ ha $^{-1}$ under all except the highest mortality rates.

\section{DISCUSSION}

\subsection{Mortality rates}

No clear trend in mortality rate with age was found in this study, suggesting that age-related mortality may generally be low and minor in comparison to other mortality factors. Similar results were obtained in separate studies reviewed in this paper. For example, oak mortality rate was found not to increase with age within first 100 years of oak lifespan in Lithuania (Ozolincius et al., 2005) where wind was the main cause $(62 \%)$ of growth-independent mortality. Monserud and Sterba (1999) found that mortality of oak was difficult to predict in logistic regressions even on large datasets. In Austrian Forest Inventory data, size and competition variables allowed corrected identification of dead oaks in only $25 \%$ of cases (percent correct classification), which was the lowest value among all deciduous and coniferous species analyzed.

Our review shows that oak mortality rate is generally correlated with stand density, which indicates possible effects of competitive interactions increasing oak mortality. In line with this observation, hyperbolic transformation of tree diameter was shown to be highly and negatively correlated with tree mortality, indicating that smaller trees experience higher mortality than larger trees (Monserud and Sterba, 1999). This pattern may differ from other hardwood species or other habitat conditions. For example, mortality of hardwoods in old-growth forests of eastern North America was found to increase with tree size, both while considering irregular (related to single disturbance event) (Woods, 2000) and regular mortality (Runkle, 2000). A study of beech (Fagus sylvatica)dominated old growth forests in France suggests that particular types of mortality events (e.g. uprooting and windbreaks) may be size-dependent (Pontailler et al., 1997).

In our dataset, however, age of the trees and openness of the habitat were correlated: oaks growing in the low-density stands were older than oaks from high-density stands. It is reasonable to assume that age itself can not be a factor decreasing 
mortality, since vigour of a tree generally decreases with age. This suggests that for oak, density-regulated allogenic mortality may be of higher importance than exogenous mortality, especially in the beginning of its lifespan. Lowest mortality rates in the sub-sample with various habitat types was probably due to the fact that two large inventory datasets (L and A2) with low mortality rates dominated this sub-set.

Oak mortality rates reviewed showed a considerable variation even within one study region. Annual mortality rate can vary between 0 and $13 \%$ with the values for the large oaks varying between 0.2 and $3.2 \%$. In oak forests in south-western Russia, variation in annual mortality rate recorded at permanent plots was more than $6 \%$ (Tab. I) and even higher if data from heavily-affected tracks of forest was included (Tab. II). These studies, however, have operated with somewhat smaller datasets as compared to other reports. Variability in annual mortality rate was 1 to $3 \%$ in the Scandinavian studies and even less (within 1\%) in the forest inventory data from Austria and Lithuania. In the last case, the size and the nature of this dataset (country-scale inventory) was a likely reason of limited variation in mortality rates. Generally, annual mortality rates under natural conditions appear to be relatively constant over a wide range of temperate forests. Franklin et al. (1987) report annual mortality ranging between 0.3 and $3.0 \%$ for the coniferous forests of American Pacific Northwest. Dendrochoronologically estimated mortality rates of canopy trees in oakhickory forests of American Middle East has been found to be on average $0.6 \%$ per year (Pedersen and McCune, 2002). Annual mortality in the mesic old-growth forests of North America has been estimated to vary between 0.5 and $3.8 \%$ with larger trees showing higher rates than smaller trees (Runkle, 2000).

Although it is natural to think that single disturbance events, rather than competition effects, should shape the temporal pattern of mortality among large and open-grown old trees, little data is available to directly test this assumption. In northern Europe, recent windfall damages prove the role of the wind as an important mortality factor (Valinger and Fridman, 1995). A study of long-term canopy dynamics in two Danish nemoral forests has reported wind as a factor accounting for 50-70\% of mortality for trees larger than $10 \mathrm{~cm}$ dbh (Wolf et al., 2004). In European mixed forests the oak appears to suffer less from wind-caused disturbances than other tree species (Falinski, 1978), which may be a result of oak's large rooting depth (Rosengren and Stjernquist, 2004) and due to this, its better anchoring capacity. This observation is supported by the assessments of the forest damage caused by the most recent windstorm that occurred in the Southern Sweden on the January 8th 2004. Deciduous forests, including oak stands, suffered substantially less damage than plantations of coniferous trees (www.svo.se).

Mortality of old ( $>150$ years old) oaks varied between 0.2 and $3.5 \%$, exhibiting lower variation than in younger cohorts. This, however, might be due to less amount of data available for older trees. In general, data on oak mortality rate becomes increasingly limited as long as consideration is moved towards old cohorts of trees ( $>150$ years). Intensive management of oaks for timber and other resources across Europe since mid- dle ages (Eliasson, 2002; Rozas, 2004) makes it difficult to obtain mortality rates of old cohorts not affected by human activities, directly - by wood harvesting, and indirectly - by changes in habitat properties (e.g. stand density, soil water and nutrient regimes). Data from regional re-inventories may also bear a bias associated with climatic conditions during the study periods, particularly - frequency of drought events, which was shown to affect oak growth and mortality in Southern Sweden (Drobyshev et al., 2007). We therefore conclude that the mortality rates reported may contain a large amount of uncertainty and time-specific effects of oak management practices. However, the reported rates likely present the best available estimates of old oak mortality in this part of Europe.

\section{MODEL CALIBRATION}

In this study, regular mortality in woodland-habitats was centered around $1 \%$ annually. The average of all available estimates was $1.6 \%$, which we considered as bearing a sampling artefact. Most of the studies reviewed have been done after episodes of above-average oak mortality had been observed in different parts of Europe, and thus, may not be representative over longer time periods. In the areas heavily affected by forest decline, annual mortality rate was higher - between 6 and 13\% (Tab. II). In the current study we used these estimates to define the possible upper limits for the mortality levels modelled.

Little empirical data is available about oak mortality rates in older age classes. In the southern Sweden, two reconstruction studies (Niklasson et al., unpublished manuscript; Lindbladh and Nilsson, 1999) provided a possibility to assess the soundness of the pre-defined mortality rates used in the model (Tab. IV). Comparison suggested that the range of variation in the mortality rates modelled was within the range of empirically observed rates. Differences in mortality rates pointed to a likely important role of site conditions and site history in controlling the mortality rates.

Oaks in the Stenbrohult landscape experienced much higher mortality than oaks at Hallands Väderö (Tab. IV). Beside possible differences in intensity of human impact between the two areas, differences in average age of the trees might explain the variation in mortality rates. Historical data suggests that already 125 years ago these trees were classified as "very old and partly rotten" (Swedish vrakekar). It is not possible to confidently assess the age of these trees, although from our knowledge of age variation in big oak trees in the southern Sweden a range between 300 and 600 years appears to be a possible estimate. Oaks at Hallands Väderö were about 350 years old at the time of last inventory (2002) and, thus, might be younger than Stenbrohult trees. Finally, the differences in the weather conditions appear as another likely source of variation in mortality rates. More humid climate at the island (Hallands Väderö), especially during the summer months, might create more favourable growth conditions as compared to the more continental weather at Stenbrohult. Oak is sensitive to summer droughts (Bridge et al., 1996; Drobyshev et al., 2007; Pilcher and Gray, 1982) and cold winters (Barklund and Wahlström, 
Table IV. Comparison of dendrochronologically or historically reconstructed mortality rates with four pre-defined mortality levels in the model. Data on reconstructed dynamics of oak densities are given in the first column for each landscape and are from Niklasson et al. (unpublished manuscript, Halland Väderö) and from Ask and Nilsson (2005, Stehbrohult). Data in the table are modelling results obtained at different mortality levels operating at empirically estimated oak densities. During model runs no input of oaks was allowed. To account for possible errors in the density estimates reconstructed, the initial oak densities was permitted to vary randomly between 15 and 25 trees/ha (Hallands Väderö) and between 10 and 15 trees/ha (Stenbrohult). Results are mean tree density (trees/ha) \pm SD for respective mortality levels.

\begin{tabular}{|c|c|c|c|c|}
\hline \multirow[t]{2}{*}{ Dataset } & \multicolumn{4}{|c|}{ Mortality levels } \\
\hline & $\begin{array}{l}M 1 \\
a-0.03 \\
f-20\end{array}$ & $\begin{array}{l}M 2 \\
a-0.05 \\
f-15\end{array}$ & $\begin{array}{l}M 3 \\
a-0.07 \\
f-13\end{array}$ & $\begin{array}{l}M 4 \\
a-0.10 \\
f-10\end{array}$ \\
\hline $\begin{array}{l}\text { Halland Väderö, } 100 \text { year dendrochronological } \\
\text { reconstruction: from } 20 \text { to } 4-5 \text { trees/ha }\end{array}$ & $3.8 \pm 0.57$ & $3.1 \pm 0.60$ & $2.4 \pm 0.54$ & $1.4 \pm 0.49$ \\
\hline $\begin{array}{l}\text { Stenbrohult, historical reconstruction: } \\
\text { change over the last } 125 \text { years: } \\
\text { from } 15 \text { to }<1 \text { tree/ha }\end{array}$ & $2.5 \pm 0.54$ & $1.9 \pm 0.49$ & $0.7 \pm 0.26$ & $0.7 \pm 0.31$ \\
\hline
\end{tabular}

1998; Thomas et al., 2002), both being more common under more continental weather.

\subsection{Model results and management implications}

Lag effect of initial oak abundance effectively decayed during 400-year simulation runs. This conclusion is based on the observation that results of 100 year runs differed from the results of 400-year runs. Given initial conditions and mortality levels being the same, it was reasonable to assume that the differences observed was a result of initial oak abundance still affecting results of shorter runs. Modelling exercise highlighted the fact that two lower input rates of oak (0-0.01 and $0.01-0.05$ tree/ha/year) would not be sufficient to meet 2 and 5 tree/ha thresholds in long-term perspective (at the time scales close to and longer than 400 years) when the abundance of oak older 200 years old will be almost exclusively a function of input rate and not of initial oak abundance at the beginning of simulation. Forest managers may choose input rate of 0.05 1 tree/ha/year to meet 2 tree/ha threshold or, alternatively, input rate of 1-5 tree/ha/year to meet 5 tree/ha threshold under all four studied mortality levels. Assuming current mortality levels (levels M2 and M3 in Tab. III) to dominate in a longterm perspective, input rate of $1-5$ tree/ha/year should also allow maintenance of the highest, 20 tree/ha threshold.

It is important to realize that the current discussion assumes a minor impact of competitive interactions among trees, the changes in the irregular mortality being the driving force behind the changes in the amount of old oaks. However, transformation of a relatively open oak woodland into, for example, a dense secondary forest would likely boost overall mortality rates through increasing its "regular" component. In such a case, possible changes in climatically-induced irregular mortality may be overshadowed by purely man-controlled changes in a land-use pattern. It is likely that such changes were one of the important factors causing the decline in the amount of hardwood component in the southern Swedish forests during the last 300 years (Eliasson, 2002; Niklasson et al., 2002).
An issue not addressed in this paper is the spatial distribution of trees, affecting dispersal possibilities for oak-associated species. A study of the endangered beetle Osmoderma eremita (Ranius and Hedin, 2001) has shown that most of the dispersal takes place within a few hundred meters from the host trees. Thus, for preservation of oak-associated species a concentration of large trees within a smaller area may be more effective than spreading the same amount of host trees across a wider territory. Following this strategy would result in considerable variation in the oak input rates into older age classes across different parts of landscape.

To conclude, defining a management strategy aimed at long-term maintenance of old oaks is complicated by the uncertainties concerning the maximum lifespan, variable mortality rates, and a long-lasting effect of the initial amount of middle-age oaks on the amount of older trees. Empirical reconstructions suggest that landscape-, site-, and tree-specific properties may all be important modifiers of mortality rates. They, therefore, should be taken into consideration while designing a new or expanding an existing network of sites with large oaks. We need better data concerning biological factors affecting mechanical properties of oak boles and its impact on mortality at the individual level, for example, the timing and the rate of spread of hollow rot. We also need more accurate information on growth rate of large oak trees at different site types, since the resulting size of the tree may be directly related to tree's sensitivity to wind damage, stress factors like temperature and precipitation extremes, or pathogen infections. Further inventory efforts and dynamic modelling of changes in the mechanical properties of the tree trunks should be helpful in obtaining this knowledge.

Acknowledgements: This study was funded by the SUFOR Project (Sustainable Forestry in Southern Sweden), Foundation of Oscar and Lili Lamm Memory, Carl Tryggers Stiftelse för Vetenskaplig Forskning (grants to I.D.), The Royal Swedish Academy of Agriculture and Forestry (grants to I.D. and J.L.), Godsförvaltaren vid Näsbyholm Stig Anderssons Foundation (grant to I.D.), the Environmental Fund of Region Skåne (grants to I.D., K.S., J.L., and M.N.), and the Regional Forestry Board of Southern Götaland (Lidellska fonden, grant to K.S.), Crafoord Foundation, Skogssällskapet i 
Göteborg, Ebbe Koch Foundation, and the Physiographic Society in Lund (grants to J.L.). We acknowledge the help of the landowners who generously provided permission to sample and logistic support: Skogsvårdsstyrelsen Södra Götaland, Götaland, Region Skåne, and Jesper Sörensen (Björnstorp och Svenstorps godsförvaltning). We thank two anonymous referees for constructive comments on earlier version of the manuscript.

\section{REFERENCES}

Ahti T., Hämet-Ahti L., and Jalas J., 1968. Vegetation zones and their sections in northwestern Europe. Ann. Bot. Fenn. 5: 169-211.

Anderson S. and Sonesson K., 1989. Skogsskadeinventering av bok och ek 1988 i Skåne, Blekinge och Halland. Skånelänens samrådsgrupp mot skogsskador, Länsstyrelsen I Kristianstads län. Rapport 7, 33 p.

Ask P. and Nilsson S.G., 2005. Det privata skogsbrukets landscap - en studie av uthålligt brukande i Stenbrohultsområde. SUFOR report, SLU, ISBN 91-5766851-5.

Auclair A.N.D., Lill J.T., and Revenga C., 1996. The role of climate variability and global warming in the dieback of Northern Hardwoods. Water Air Soil Pollut. 91: 163-186.

Barklund P. and Wahlström K. 1998. Death of oaks in Sweden since 1987. In: Cech T.L. and Hartman G.T.C. (Eds.), Disease/environment interaction in forest decline. Proceedings of a workshop of the working party Disease/environment interactions in forest decline IUFRO 7.02.06, 16th March-21 March 1998, Vienna, Austria: Federal Forest Research Centre, 193.

Blomberg P., Från Bjuv till Östra Göinge, 2004. In: Blomberg P. and Billqvist M. (Eds.), Skånska jätteträd, Naturskyddföreningen i Skåne, Lund, pp. 75-118.

Blomberg P., Billqvist M., and Ivarsson K., 2004. Personliga porträtt av skånska jättar. In: Blomberg P., Billqvist M. (Eds.), Skånska jätteträd, Naturskyddföreningen i Skåne, Lund, pp. 119-142.

Bridge M.C., Gasson P.E., and Cutler D.F., 1996. Dendroclimatological observations on trees at Kew and Wakehurst Place: Event and pointer years. Forestry 69: 263-269.

Demchik M.C. and Sharpe W.E., 2000. The effect of soil nutrition, soil acidity and drought on northern red oak (Quercus rubra L.) growth and nutrition on Pennsylvania sites with high and low red oak mortality. For. Ecol. Manage. 136: 199-207.

Dobrovolsky A., 2007. Dynamics of natural mortality and tree structure in Oranienbaum park. Southern Swedish Forest Research Centre, SLU Alnarp No. 92, 41 p.

Drobyshev I., Linderson H., Sonesson K. 2007. Temporal mortality pattern of pedunculate oaks in southern Sweden. Dendrochronologia 24 97-108.

Efron B. and Tibshirani R.J., 1994. An Introduction to the bootstrap, Chapman \& Hall.

Eliasson P., 2002. Skog, makt och människor. En miljöhistoria om svensk skog 1800-1875. KSLA.

Eliasson P., 2004. Eek uthi stoor myckenhet. Ekens plats i bondens landscap. In: Blomberg P., Billqvist M. (Eds.), Skånska jätteträd, Naturskyddföreningen i Skåne, Lund, pp. 147-151.

Falinski J.B., 1978. Uprooted trees, their distribution and influence in the primeval forest biotop. Vegetatio 38: 175-183.

Franklin J.F., Shugart H.H., and Harmon M.E., 1987. Tree death as an ecological process. Bioscience 37: 550-556.

Fredén C., 2002. Geology. The national atlas of Sweden. SNA Förlag, Stockholm.
Hedin J., 2003. Metapopulation ecology of Osmoderma eremita - dispersal, habitat quality and habitat history, Ph. D. theses Dep. of Ecology, Lund University, Lund.

Lindbladh M., Niklasson M., and Nilsson S.G., 2003. Long-time record of fire and open canopy in a high biodiversity forest in southeast Sweden. Biol. Conserv. 114: 231-243.

Lindbladh M. and Nilsson S.G., 1999. Skog och träd i kulturlandskapet. Vegetationshistorien i Stenbrohult utifrån biologiska och historiska arkiv. Svensk Botanisk Tidskrift 93: 19-30.

Löf M., 2001. Uthålligt skogsbruk i ädellövskog. Skogsvetenskapliga fakulteten, SLU, Uppsala.

Monserud R.A. and Sterba H., 1999. Modeling individual tree mortality for Austrian forest species. For. Ecol. Manage. 113: 109-123.

Naumenko I.M., 1949. Drying out of oak in Voronezh strict nature reserve and forestries of Voronezh region, its causes and practical measures. Proceedings of the Voronezh strict nature reserve III, 6-33.

Niklasson M., Lindbladh M., and Bjorkman L., 2002. A long-term record of Quercus decline, logging and fires in a southern Swedish FagusPicea forest. J. Veg. Sci. 13: 765-774.

Nilsson N.E., 1996. Forests. Swedish National Atlas. SNA Förlag, Stockholm.

Nilsson S.G., Niklasson M., Hedin J., Aronsson G., Gutowski J.M., Linder P., Ljungberg H., Mikusinski G., and Ranius T., 2002. Densities of large living and dead trees in old-growth temperate and boreal forests. For. Ecol. Manage. 161: 189-204.

Osipov V.V., 1989. Stand growth conditions in the Central Russian foreststeppe zone. In: Osipov V.V., Selochnik N.N., and Ilyushenko A.F., et al. (Eds.), The state of oak forests in the forest-steppe zone, Nauka Publishing House, Moscow, pp. 5-18.

Osipov V.V. and Selochnik N.N., 1989. The state of oak forests in the Central Russian forest-steppe after materials of reconnoiering inspections in 1984-1987. In: Osipov V.V., Selochnik N.N., Ilyushenko A.F., et al. (Eds.), The state of oak forests in the forest-steppe zone, Nauka Publishing House, Moscow, pp. 199-205.

Ozolincius R., Miksys V., and Stakenas V., 2005. Growth-independent mortality of Lithuanian forest tree species. Scand. J. For. Res. 20: $153-160$.

Pedersen B.S., 1999. The mortality of midwestern overstory oaks as a bioindicator of environmental stress. Ecol. Appl. 9: 1017-1027.

Pedersen B.S. and McCune B., 2002. A non-invasive method for reconstructing the relative mortality rates of trees in mixed-age, mixedspecies forests. For. Ecol. Manage. 155: 303-314.

Pilcher J. and Gray S., 1982. The relationships between oak tree growth and climate in Britain. J. Ecol. 70: 297-304.

Pontailler J.Y., Faille A., and Lemee G., 1997. Storms drive successional dynamics in natural forests: a case study in Fontainebleau forest (France). For. Ecol. Manage. 98: 1-15.

Ranius T. and Hedin J., 2001. The dispersal rate of a beetle, Osmoderma eremita, living in tree hollows. Oecologia 126: 363-370.

Ranius T. and Jansson N., 2000. The influence of forest regrowth, original canopy cover and tree size on saproxylic beetles associated with old oaks. Biol. Conserv. 95: 85-94.

Rosengren U. and Stjernquist I., 2004. Gå på djupet! Om rotdjup och rotprodukiton i olika skogstyper. SUFOR report. ISBN 91-576-66172. SUFOR Project, Lund.

Rozas V., 2004. A dendroecological reconstruction of age structure and past management in an old-growth pollarded parkland in northern Spain. For. Ecol. Manage. 195: 205-219.

Runkle J.R., 2000. Canopy tree turnover in old-growth mesic forests of eastern North America. Ecology 81: 554-567. 
Selochnik N.N., 1989. On the oak forest decline causes. In: Osipov V.V., Selochnik N.N., Ilyushenko A.F., et al. (Eds.), The state of oak forests in the forest-steppe zone, Nauka Publishing House, Moscow, pp. $48-54$.

Selochnik N.N. and Kondrashova N.K., 1989. The role of diseases in weakening the decline of oak forests. In: Osipov V.V., Selochnik N.N., Ilyushenko A.F., et al. (Eds.), The state of oak forests in the forest-steppe zone, Nauka Publishing House, Moscow, pp. 115-137.

Senitza E., 1993. Eischenschadinventur 1987-1993. Hrsg.: Hauptverband der Land- und Forstwirtschaftsbetriebe Österreichs, Vienna, 19 p.

Shugart H.H., 1987. Dynamic ecosystem consequences of tree birth and death patterns. Bioscience 37: 596-602.

Silvertown J.V. and Charlesworth D., 2001. Introduction to plant population biology, Blackwell Science.

Sjörs H., 1963. Amphi-Atlantic zonation, Nemoral to Arctic. In: Löve Á., Löve D. (Eds.), North Atlantic biota and their history, Oxford, pp. 109-125.
Sokal R.R. and Rolf F.J., 1995. Biometry: the principles and practice of statistics in biological research, W.H. Freeman, New York.

Thomas F.M., Blank R., Hartmann G., 2002. Abiotic and biotic factors and their interactions as causes of oak decline in Central Europe. For. Pathol. 32: 277-307.

Tiefenbacher H., 1996. Silvicultural planning under conditions of environmental change: Evaluation of options in a dieback in Austrian oak forests. For. Ecol. Manage. 83: 133-136.

Valinger E. and Fridman J., 1995. Vind- och snöskadoromfattning och motåtgärder. Skog \& Forskning 3: 40-45.

Wolf A., Moller P.F., Bradshaw R.H.W., and Bigler J., 2004. Storm damage and long-term mortality in a semi-natural, temperate deciduous forest. For. Ecol. Manage. 188: 197-210.

Woods K.D., 2000. Dynamics in late-successional hemlock-hardwood forests over three decades. Ecology 81: 110-126.

Zhao D.H., Borders B., and Wilson M., 2004. Individual-tree diameter growth and mortality models for bottomland mixed-species hardwood stands in the lower Mississippi alluvial valley. For. Ecol. Manage. 199: 307-322. 